\title{
PENGARUH SELF EFFICACY, REWARD AND PUNISHMENT, DAN ASIMETRI INFORMASI TERHADAP BUDGETARY SLACK: STUDI EKSPERIMEN PADA KONTEKS PENGANGGARAN PARTISIPATIF
}

\author{
Fitri Ardiyani \\ Prodi Akuntansi Universitas Negeri Yogyakarta \\ ardhiyawardani07@gmail.com \\ Prof. Sukirno, M.Si., Ph.D. \\ Staf Pengajar Jurusan Pendidikan Akuntansi Universitas Negeri Yogyakarta
}

\begin{abstract}
Abstrak : Pengaruh Self Efficacy, Reward And Punishment, Dan Asimetri Informasi Terhadap Budgetary Slack: Studi Eksperimen Pada Konteks Penganggaran Partisipatif. Penelitian ini bertujuan untuk mengetahui: (1) pengaruh Self Efficacy terhadap Budgetary Slack; (2) pengaruh Reward and Punishment terhadap Budgetary Slack; dan (3) pengaruh Asimetri Informasi terhadap Budgetary Slack. Penelitian ini merupakan penelitian eksperimen dengan desain faktorial $2 \times 2 \times 2$ between subject. Sampel penelitian adalah mahasiswa Program Studi Akuntansi dan Pendidikan Akuntansi angkatan 2014 Universitas Negeri Yogyakarta sebanyak 154 mahasiswa. Metode pengambilan data menggunakan metode angket. Hipotesis penelitian diolah menggunakan alat uji statistik two ways ANOVA menggunakan General Linear Model. Hasil penelitian ini menunjukkan bahwa: (1) Tingkatan Self Efficacy terbukti tidak berpengaruh terhadap Budgetary Slack. Hal tersebut ditunjukkan dengan $p$-value signifikan sebesar 0,928 $>0,05$ dan $\mathrm{F}_{\text {hitung }}<\mathrm{F}_{\text {tabel, }}$, yaitu 0,008 $<3,90$. (2) Reward and Punishment terbukti berpengaruh terhadap Budgetary Slack yang ditunjukkan dengan $p$ value signifikan 0,004 < 0,005 dan $\mathrm{F}_{\text {hitung }}>\mathrm{F}_{\text {tabel, }}$ yaitu 8,362 > 3,90. (3) Tingkatan Asimetri Informasi terbukti tidak berpengaruh terhadap Budgetary Slack. Hal tersebut ditunjukkan dengan p-value signifikan sebesar 0,667 $>0,005$ dan $\mathrm{F}_{\text {hitung }}<\mathrm{F}_{\text {tabel, }}$ yaitu $0,186<3,90$.
\end{abstract}

Kata kunci: Budgetary Slack, Self Efficacy, Reward, Punishment, Asimetri Informasi.

\begin{abstract}
The Effect Of Self Efficacy, Reward And Punishment And Information Asymmetry On Budgetary Slack: An Experimental Study On Budget Participation Context

The purposes of this research are to find out: (1) the effect of Self Efficacy on Budgetary Slack; (2) the effect of Reward and Punishment on Budgetary Slack; and (3) the effect of Information Asymmetry on Budgetary Slack. This research was an experimental research with factorial design $2 \times 2 \times 2$ between subject. The research sample were students majoring in Accounting and Accounting Education year of 2014 Yogyakarta State University as many as 154 students. . Data were collected through questionnaire. Hypothesis were analyzed using a statistical test two-way ANOVA using the General Linear Model. The results of this research show that: (1) The level of Self Efficacy doesn't affect the Budgetary Slack. This is shown by significant p-value 0,928 >0,05 and $F_{\text {counted }}<F_{\text {table }} 0,008<3,90$. (2) Reward and Punishment affects the Budgetary Slack as shown by significant p-value 0,004 <0,005 and $F_{\text {counted }}>F_{\text {table }} 8,362>3,90$. (3) The level of Information Asymmetry doesn't affect the Budgetary Slack. This is shown by significant $p$-value 0,667>0,005 and $F_{\text {counted }}<F_{\text {table }} 0,186<3,90$.
\end{abstract}

Keywords: Budgetary Slack, Self Efficacy, Reward, Punishment, Information Asymmetry. 


\section{JURNAL NOMINAL / VOLUME VI NOMOR 1 / TAHUN 2017}

\section{PENDAHULUAN}

Setiap perusahaan atau organisasi tentu memiliki tujuan yang ingin dicapai kedepannya. Untuk mencapai tujuan tersebut, perusahaan biasanya akan menyusun sebuah perencanaan strategi. Salah satu kegiatan yang dapat dilakukan manajemen untuk membuat sebuah perencanaan strategi adalah dengan menyusun anggaran. Menurut Anthony dan Govindarajan (2011: 94) anggaran merupakan suatu alat yang penting untuk perencanaan dan pengendalian jangka pendek yang efektif dalam sebuah organisasi.

Mengingat betapa pentingnya anggaran bagi suatu perusahaan, maka proses penyusunan anggaran tidak dapat dipandang sebelah mata oleh pihak manajemen. Anggaran yang disusun dapat berjalan dengan efektif apabila memenuhi beberapa persyaratan, salah satunya adalah anggaran harus mendukung semua tingkatan dalam organisasi mulai dari tingkat bawah, menengah, hingga atas. Oleh karena itu penyusunan anggaran dengan pendekatan partisipasi anggaran atau penganggaran partisipatif menjadi sangat diperlukan. Menurut Rahayu dan Rachman (2013: 11) self-imposed budget atau penganggaran partisipatif (participative budgeting) merupakan proses penyusunan anggaran yang melibatkan seluruh karyawan (manajer pada semua tingkatan) dalam organisasi.

Di sisi lain adanya penganggaran partisipatif akan memunculkan perilaku negatif dari manajer bawah yaitu kecenderungan mereka untuk melakukan Budgetary Slack (Senjangan Anggaran). Adanya Senjangan Anggaran ini akan mengakibatkan kegunaan anggaran sebagai alat menilai atau mengevaluasi kinerja manajerial menjadi disfungsi karena kinerja manajer akan terlihat baik dengan mereka melakukan Budgetary Slack.

Senjangan Anggaran yang dilakukan oleh manajer bawah dapat disebabkan karena adanya kondisi Asimetri Informasi yaitu ketidakseimbangan informasi yang dimiliki oleh manajer atas dan manajer bawah. Manajer bawah seringkali menggunakan kondisi tersebut sebagai kesempatan untuk melakukan Budgetary Slack karena merasa manajer atas tidak akan mengetahui tindakannya.

Perusahaan juga seringkali menerapkan sistem Reward dan Punishment untuk memotivasi kinerja karyawannya. Pemberian Reward dan Punishment ini juga memengaruhi kecenderungan seseorang dalam melakukan Senjangan Anggaran (Budgetary Slack) dalam penganggaran partisipatif. Individu cenderung bekerja hanya untuk mendapatkan Reward atau menghindari 


\section{JURNAL NOMINAL / VOLUME VI NOMOR 1 / TAHUN 2017}

Punishment, sehingga mereka akan melakukan berbagai cara untuk mendapatkan apa yang mereka inginkan, meskipun dengan cara yang salah.

Di sisi lain, individu dalam melakukan pekerjaannya juga cenderung melihat atau mengukur kemampuan dirinya. Begitu pula yang dilakukan seorang bawahan ketika menyusun sebuah anggaran, mereka akan melihat kemampuan dirinya sebelum mengambil keputusan dalam menentukan seberapa besar target anggaran yang akan ditetapkan. Keyakinan seseorang mengenai peluangnya untuk berhasil mencapai tugas tertentu disebut dengan Self Efficacy (Kreitner dan Kinicki, 2003).

Menurut Erina dan Suartana (2016) Senjangan Anggaran adalah perbedaan anggaran yang dinyatakan dan estimasi anggaran terbaik yang secara jujur dapat diprediksikan. Manajer bawah melakukan Senjangan Anggaran dengan cara menurunkan pendapatan atau menaikkan biaya agar mereka mudah untuk mencapai anggaran tersebut, sehingga kinerja mereka terlihat baik di mata atasan.

Falikhatun (2007) menyatakan bahwa manajer menciptakan Budgetary Slack karena beberapa alasan, yaitu (1) kinerja manajer tingkat bawah akan terlihat baik di mata atasan apabila target yang ditetapkan dapat tercapai, (2) Budgetary
Slack digunakan untuk mengatasi ketidakpastian dalam memprediksi masa yang akan datang, (3) pengalokasian sumber daya akan dilakukan berdasarkan proyeksi anggaran biaya, sehingga senjangan membuatnya fleksibel.

Pencetus teori Self Efficacy, Bandura (1986) dalam Silfiana (2015) mendefinisikan Self Efficacy adalah judgment seseorang terhadap kemampuan dirinya sendiri dalam mencapai tingkatan kinerja yang diinginkan atau ditentukan, yang akan memengaruhi tindakan selanjutnya. Self Efficacy dapat dibentuk dan ditumbuhkan melalui empat faktor yaitu: (1) mastery experience, (2) vicarious experience, (3) verbal persuasion, dan (4) psysiological state.

Dalam konteks penyusunan anggaran secara partisipatif, manajer bawah dengan Self Efficacy tinggi memiliki keyakinan bahwa mereka mampu mencapai target anggaran yang telah mereka tetapkan sesuai dengan kemampuan terbaik mereka. Berbeda dengan manajer bawah yang memiliki Self Efficacy rendah, mereka tidak yakin dapat mencapai target anggaran sehingga mereka cenderung melakukan Senjangan Anggaran agar target anggaran lebih mudah dicapai. Menurut Abdullah (2013) Self Efficacy yang tinggi dapat mengurangi kecenderungan praktik Senjangan Anggaran yang akan dilakukan 
oleh manajer bawah. Sebaliknya Self Efficacy rendah akan mendorong manajer untuk menciptakan Senjangan Anggaran.

H1: Pada manajer penyusun anggaran dengan Self Efficacy tinggi kecenderungan untuk melakukan Budgetary Slack lebih rendah daripada manajer dengan Self Efficacy rendah.

Reward merupakan padanan kata dari kompensasi, penghargaan, ganjaran, imbalan atau hadiah. Menurut Wibisono (2015) Reward merupakan feedback positif yang diberikan oleh perusahaan atas pencapaian yang telah dilakukan oleh karyawan. Dalam hal proses penyusunan anggaran dengan partisipasi, Reward diberikan ketika manajer bawah mampu mencapai atau melebihi target yang telah ditetapkan dalam rancangan anggaran yang telah disusun. Hal ini membuat bawahan cenderung memberikan informasi yang bias agar anggaran mudah dicapai sehingga bawahan mendapatkan Reward atas pencapaian anggaran yang menandakan prestasi mereka baik. Hal ini sesuai dengan yang diungkapkan oleh Desmayani dan Suardhika (2016) bahwa seseorang menyadari jika memiliki prestasi yang tinggi maka akan mendapatkan Reward yang besar, adanya Reward yang besar menimbulkan Budgetary Slack meningkat.

Punishment merupakan kebalikan dari sistem Reward. Menurut Ivancevich et.al (2007), Punishment adalah suatu konsekuensi yang tidak menyenangkan atau tidak diinginkan yang diberikan oleh atasan atas suatu perilaku tertentu yang telah dilakukan. Pada konteks penganggaran secara partisipasi, Punishment diberikan bagi manajer bawah apabila pencapaian kinerja tidak sesuai dengan anggaran yang diajukan, baik itu kurang maupun melebihi target anggaran. Penerapan sistem Punishment seperti itu diharapkan manajer bawah akan benar-benar melakukan pertimbangan yang matang sebelum menetapkan target anggaran karena selisih lebih atau kurang pada pencapaian kinerja akan diberikan hukuman berupa pemotongan gaji atau denda. Hal ini diharapkan pula dapat mengurangi kecenderungan manajer bawah untuk menciptakan Senjangan Anggaran.

H2: Manajer penyusun anggaran yang diberikan Reward cenderung melakukan Budgetary Slack sementara manajer penyusun anggaran yang diberikan Punishment cenderung menghindari Budgetary Slack.

Rahmah dan Sembiring (2014) menyatakan bahwa Asimetri Informasi merupakan suatu kondisi dimana manajer bawah (agent) memiliki lebih banyak informasi atas prospek dan kondisi unit pertanggungjawabannya dibandingkan 
dengan manajer atas (principal). Dalam konteks penganggaran partisipatif, manajer atas memberikan wewenang kepada manajer bawah untuk menyusun anggaran yang sesuai dengan kondisi yang terjadi pada masing-masing pusat pertanggungjawaban. Pada praktiknya, adanya partisipasi anggaran ini dipandang sebagai kesempatan bagi manajer bawah untuk tidak mengungkapkan seluruh informasi yang mereka miliki tentang pusat pertanggungjawabannya karena mereka merasa bahwa atasan tidak mengetahui kondisi sebenarnya. Hal ini mengakibatkan kecenderungan manajer bawah untuk menciptakan Senjangan Anggaran pada anggaran yang akan mereka ajukan. Tujuannya adalah agar target anggaran tersebut dapat dengan mudai dicapai sehingga kinerja mereka akan terlihat baik di mata atasan. Ardanari dan Putra (2014) menyebutkan bahwa Asimetri Informasi memiliki pengaruh yang positif dan signifikan terhadap Senjangan Anggaran, artinya semakin tinggi tingkat Asimetri Informasi maka semakin tinggi pula kemungkinan manajer melakukan Senjangan Anggaran.

H3: Pada manajer penyusun anggaran yang berada dalam kondisi Asimetri Informasi tinggi kecenderungan untuk melakukan Budgetary Slack lebih tinggi daripada manajer dalam kondisi Asimetri Informasi rendah.

Berdasarkan uraian di atas, maka peneliti tertarik untuk melakukan kajian dan penelitian lebih lanjut mengenai "Pengaruh Self Efficacy, Reward and Punishment, dan Asimetri Informasi terhadap Budgetary Slack: Studi Eksperimen pada Konteks Penganggaran Partisipatif”.

\section{A. METODE PENELITIAN}

Penelitian ini merupakan penelitian eksperimen dengan menggunakan rancangan acak lengkap eksperimen (complete randomized experimental design), yakni suatu rancangan eksperimen yang menggunakan sampel secara acak bebas dari unit eksperimen dikaitkan pada perlakuan (treatment) (Sugiharto, 2009). Penelitian ini menggunakan desain faktorial $2 \times 2 \times 2$ dan between subject.

\begin{tabular}{|c|c|c|c|c|}
\hline \multirow{4}{*}{} & \multicolumn{2}{|c|}{$\begin{array}{c}\text { AI } \\
\text { Rendah }\end{array}$} & \multicolumn{2}{c|}{$\begin{array}{c}\text { AI } \\
\text { Tinggi }\end{array}$} \\
\cline { 2 - 5 } & $\begin{array}{c}S E \\
\text { Rendah }\end{array}$ & $\begin{array}{c}S E \\
\text { Tinggi }\end{array}$ & $\begin{array}{c}S E \\
\text { Rendah }\end{array}$ & $\begin{array}{c}S E \\
\text { Tinggi }\end{array}$ \\
\hline$R$ & K 1 & K 2 & K 3 & K 4 \\
\hline$P$ & K 5 & K 6 & K 7 & K 8 \\
\hline
\end{tabular}

\section{Tabel 1. Desain Eksperimen}

Keterangan:

AI : Asimetri Informasi 


$\begin{array}{ll}\mathrm{SE} & \text { : Self Efficacy } \\ \mathrm{R} & : \text { Reward } \\ \mathrm{P} & : \text { Punishment } \\ \mathrm{K} & \text { : Kasus }\end{array}$

Populasi dari penelitian ini adalah mahasiswa Program Studi Akuntansi dan Pendidikan Akuntansi Fakultas Ekonomi Universitas Negeri Yogyakarta angkatan 2014. Adapun sampel penelitian berjumlah 154 mahasiswa. Teknik pengambilan sampel dengan metode purposive sampling, yaitu partisipan yang dipilih memiliki kriteria tertentu. Kriteria yang dimaksud adalah mahasiswa yang telah lulus atau sedang menempuh mata kuliah Akuntansi Manajemen atau Sistem Pengendalian Manajemen atau Penganggaran.

Partisipan diposisikan sebagai manajer bawah bagian produksi yang bertugas untuk memproduksi pesawat terbang kertas. Prosedur eksperimen yaitu sebagai berikut:

1. Partisipan diminta untuk melakukan tugas produksi 1 mengetahui tingkat kemampuan mereka.

2. Partisipan diminta untuk menetapkan target produksi (Target I) untuk tugas produksi selanjutnya (tugas produksi 2).

3. Partisipan diminta untuk melakukan tugas produksi 2. Partisipan yang dapat mencapai target I pada tugas produksi 2 dikelompokkan ke dalam Self Efficacy tinggi. Sementara partisipan yang tidak dapat mencapai target I pada tugas produksi 2 dikelompokkan ke dalam Self Efficacy rendah.

4. Pemberian informasi mengenai treatment Reward dan Punishment.

5. Partisipan diminta untuk menetapkan target produksi II untuk tugas produksi 3.

6. Partisipan diminta untuk melakukan tugas produksi 3. Partisipan yang mendapatkan perlakuan Reward akan diberi Reward tambahan apabila tugas produksi 3 melebihi dari target produksi II. Sementara partisipan yang mendapat perlakuan Punishment akan diberikan denda apabila hasil tugas produksi 3 kurang atau lebih dari target produksi II.

7. Pemberian informasi untuk treatment Asimetri Informasi.

8. Partisipan diminta menetapkan target produksi III dengan mempertimbangkan berbagai treatment yang telah didapatkan.

9. Partisipan diminta untuk mengisi pernyataan manipulation check.

Penelitian ini menggunakan acuan instrumen dari Arthaswadaya (2015) untuk membangun desain instrumen Asimetri Informasi dan Silfiana (2015) untuk membangun desain instrumen Self Efficacy. Kemudian peneliti melakukan modifikasi dan penyesuaian pada kedua 
instrumen tersebut untuk memenuhi kebutuhan penelitian eksperimen ini. Peneliti juga melakukan modifikasi dan penyesuaian desain instrumen untuk Reward and Punishment dari penelitian Nugrahani (2005) dari treatment skema kompensasi. Pengukuran variabel penelitian menggunakan variabel dummy dengan skor 0 dan 1.

Peneliti melakukan pilot test untuk mengetahui tingkat pemahan subjek terhadap kasus yang diberikan. Pilot test dilakukan kepada mahasiswa Pendidikan Akuntansi angkatan 2013 sebanyak 32. Uji validitas menggunakan teknik face validity. Untuk menguji reliabilitas dalam penelitian ini digunakan koefisien Cronbach's Alpha. Suatu construct atau variabel dikatakan reliabel jika memberikan nilai Cronbach's Alpha >0,60. Teknik analisis data dengan statistik deskriptif, pengujian prasyarat (Uji Normalitas dan Uji Varians), dan pengujian hipotesis menggunakan alat uji statistik two ways ANOVA menggunakan General Linear Model untuk mengetahui pengaruh utama dari tiap variabel independen terhadap variabel dependen.

\section{B. HASIL PENELITIAN DAN PEM- BAHASAN}

\begin{tabular}{|l|l|c|r|}
\hline \multirow{2}{*}{ No. } & $\begin{array}{c}\text { Program } \\
\text { Studi }\end{array}$ & Kelas & Jumlah \\
\hline 1. & Akuntansi & $\mathrm{A}$ & 21 \\
\cline { 3 - 4 } & $\mathrm{B}$ & 27 \\
\cline { 3 - 4 } & Pendidikan & $\mathrm{U}$ & 27 \\
\hline \multirow{2}{*}{ Akuntansi } & $\mathrm{B}$ & 38 \\
\cline { 3 - 4 } & $\mathrm{U}$ & 21 \\
\hline Jumlah & 154 \\
\hline \multicolumn{2}{|l|}{$\begin{array}{l}\text { Tidak memenuhi syarat untuk } \\
\text { diolah }\end{array}$} \\
\hline \multicolumn{2}{|l|}{ Data subjek yang dapat diolah } \\
\hline
\end{tabular}

Tabel 2. Deskripsi Data Penelitian

Sumber: Data primer diolah, 2017

Dari jumlah tersebut, untuk setiap kelas dibagikan secara acak angket dengan 8 kasus perlakuan yaitu kasus 1 hingga 8 .

\section{Statistik Deskriptif}

\section{a. Statistik Deskriptif Umur}

Partisipan yang mengikuti eksperimen mayoritas berumur 20 tahun yaitu sebanyak 123 orang, diikuti dengan partisipan yang berumur 21 tahun yaitu sebanyak 24 orang. Partisipan yang berumur 19 tahun berjumlah 5 orang, sementara sisanya adalah partisipan yang berumur 22 tahun dan lebih dari 22 
tahun (>22) yaitu masing-masing sebanyak 1 orang.

\section{b. Statistik Deskriptif Gender}

Partisipan yang mengikuti eksperimen ini mayoritas adalah perempuan dengan jumlah 122 orang (79\%), sedangkan partisipan yang berjenis kelamin laki-laki sebanyak 32 orang $(21 \%)$.

\section{c. Statistik Deskriptif IPK}

Partisipan yang mengikuti eksperimen ini mayoritas memiliki IPK > 3,51 sedangkan partisipan dengan IPK $<3,00$ hanya 1 orang. Sisanya sebanyak 12 orang dengan IPK 3,00 - 3,25 dan 44 orang dengan IPK 3,26 - 3,50.

\section{d. Statistik Deskriptif Mata Kuliah} yang Sedang/Telah Ditempuh

Partisipan yang sedang atau telah menempuh mata kuliah akuntansi manajemen dan sistem pengendalian manajemen sebanyak 75 orang. Jumlah tersebut sama dengan partisipan yang sedang atau telah menempuh mata kuliah akuntansi manajemen dan penganggaran, sedangkan partisipan yang hanya sedang atau telah menempuh mata kuliah akuntansi manajemen saja dan mata kuliah penganggaran saja, masing-masing sebanyak 2 orang.

\section{e. Statistik Deskriptif Data Variabel}

Statistik deskriptif variabel Budgetary Slack menunjukkan nilai mean Budgetary Slack sebesar 0,053. Nilai Budgetary Slack minimum adalah -0,900, sedangkan nilai maksimum adalah 0,710 sehingga memiliki range sebesar 1,610.

Statistik deskriptif variabel Self Efficacy menunjukkan bahwa partisipan yang memiliki Self Efficacy rendah sebanyak 74 orang, sedangkan partisipan dengan Self Efficacy tinggi sebanyak 80 orang.

Statistik deskriptif variabel Reward and Punishment menunjukkan bahwa partisipan yang mendapatkan perlakuan Reward dan Punishment jumlahnya sama yaitu sebanyak 77 orang.

Statistik deskriptif variabel Asimetri Informasi menunjukkan bahwa partisipan yang mendapatkan kasus Asimetri Informasi rendah adalah sebanyak 78 orang, sedangkan partisipan yang mendapatkan kasus Asimetri Informasi tinggi jumlahnya 76 orang.

\section{Hasil Pengujian Hipotesis dan}

\section{Pembahasan}

Tabel berikut ini menunjukkan hasil pengujian hipotesis. 
Tabel 3. Hasil Uji Hipotesis

Dependent Variable: Budgetary Slack

\begin{tabular}{|c|c|c|c|}
\hline $\mathbf{X}$ & $\mathbf{F}$ & Sig. & Keterangan \\
\hline SE & 0.008 & 0.928 & $\begin{array}{c}\mathrm{H}_{1} \text { tidak } \\
\text { didukung }\end{array}$ \\
\hline RP & 8.362 & 0.004 & $\mathrm{H}_{2}$ didukung \\
\hline AI & 0.186 & 0.667 & $\begin{array}{l}\mathrm{H}_{3} \text { tidak } \\
\text { didukung }\end{array}$ \\
\hline
\end{tabular}

Sumber: Data primer diolah, 2017

a. Pengaruh Self Efficacy terhadap Budgetary Slack

Hipotesis pertama $\left(\mathrm{H}_{1}\right)$ menyatakan bahwa pada manajer penyusun anggaran dengan Self Efficacy tinggi kecenderungan untuk melakukan Budgetary Slack lebih rendah daripada manajer dengan Self Efficacy rendah. Berdasarkan hasil pengujian, diperoleh $\mathrm{F}_{\text {hitung }}$ sebesar 0,008 dan $\mathrm{F}$ tabel yaitu 3,90. Nilai p-value signifikansi untuk $\mathrm{H}_{1}$ sebesar 0,928 (lebih besar dari 0,05) dan $\mathrm{F}$ hitung $0,008<\mathrm{F}$ tabel 3,90 , maka $\mathrm{H}_{1}$ yang diajukan dalam penelitian ini tidak didukung.

Hipotesis 1 dalam penelitian ini diajukan dengan berlandaskan pada teori mengenai Self Efficacy yang dicetuskan oleh Bandura pada tahun 1977. Teori mengenai Self Efficacy kemudian semakin berkembang dan diakui oleh para ahli psikologi sebagai prediktor atas perilaku individu selanjutnya. Berdasarkan teori mengenai Self Efficacy tersebut kemudian peneliti menyusun hipotesis bahwa terdapat perbedaan kecenderungan Budgetary Slack pada kondisi tingkatan Self Efficacy yang berbeda pula. Manajer penyusun anggaran dengan Self Efficacy tinggi memiliki kecenderungan melakukan Budgetary Slack yang lebih rendah daripada manajer dengan Self Efficacy rendah.

Hipotesis pertama telah disusun berdasarkan dukungan teori yang cukup, memiliki definisi konstruk yang jelas, dan hubungan pengaruh Self Efficacy terhadap Budgetary Slack dapat dijelaskan melalui kerangka berpikir yang logis. Ketidakmampuan Self Efficacy dalam memengaruhi Budgetary Slack dimungkinkan terjadi karena penelitian ini masih mengandung kelemahan pada metode, pemilihan partisipan dan implementasi eksperimen. Selain itu Self Efficacy merupakan faktor psikologis yang memang sulit untuk dikendalikan atau diubah hanya dalam waktu singkat saat penelitian dilakukan.

Hasil penelitian ini sejalan dengan penelitian yang dilakukan 
oleh Ira A. Abdullah (2013) yang menunjukkan bahwa Self Efficacy memiliki pengaruh yang kurang signifikan terhadap Budgetary Slack. Penelitian tersebut juga mengungkapkan bahwa tidak ada perbedaan rata-rata secara signifikan pada nilai Budgetary Slack dengan tingkatan Self Efficacy yang berbeda.

b. Pengaruh Reward and Punishment terhadap Budgetary Slack

Hipotesis kedua menyatakan bahwa pada manajer penyusun anggaran yang diberikan Reward cenderung melakukan Budgetary Slack sementara manajer penyusun anggaran yang diberikan Punishment cenderung menghindari Budgetary Slack. Hasil pengujian $\mathrm{H}_{2}$ menunjukkan adanya perbedaan nilai Budgetary Slack pada pemberian Reward dan Punishment dengan $\mathrm{F}$ hitung sebesar 8,362 lebih besar dari $\mathrm{F}$ tabel yaitu 3,90. Hasil $p$ value 0,004 ( $p$-value $<0,05)$ cukup signifikan. Nilai rata-rata (mean) Budgetary Slack dengan kondisi pemberian Reward sebesar 0,084706 sedangkan pemberian Punishment memiliki mean sebesar 0,023031.

Hasil pengujian tersebut menunjukkan bahwa manajer bawah yang diberikan Reward cenderung melakukan Budgetary Slack lebih tinggi daripada manajer bawah yang diberikan Punishment. Hal ini menunjukkan bahwa hipotesis kedua $\left(\mathrm{H}_{2}\right)$ yang diajukan dalam penelitian ini didukung atau diterima.

Hasil penelitian ini sesuai dengan penelitian yang dilakukan oleh Ni Made Mila Rosa Desmayani dan I Made Sadha Suardikha (2016) yang menunjukkan bahwa pemberian Reward berpengaruh positif terhadap Budgetary Slack, hal ini dikarenakan pemberian Reward didasarkan pada pencapaian target anggaran sehingga bawahan cenderung melakukan Senjangan Anggaran agar anggaran mudah dicapai dan dapat memperoleh Reward yang besar dari atasan.

\section{c. Pengaruh Asimetri Informasi terhadap Budgetary Slack}

Hipotesis ketiga menyatakan bahwa pada manajer penyusun anggaran yang berada dalam kondisi Asimetri Tinggi kecenderungan untuk melakukan Budgetary Slack lebih tinggi daripada manajer dalam kondisi Asimetri Informasi rendah. Berdasarkan hasil pengujian, diperoleh nilai $p$-value signifikansi sebesar 0,667>0,05 dan $\mathrm{F}$ hitung 0,186 $<\mathrm{F}$ tabel 3,90, dengan demikian $\mathrm{H}_{3}$ 
yang diajukan dalam penelitian ini tidak didukung atau tidak terbukti.

Meskipun nilai $p$-value signifikansi dalam penelitian lebih dari 0,05 , akan tetapi hasil penelitian ini sesuai dengan teori yang melandasi apabila dilihat dari nilai mean Budgetary Slacknya. Hasil penelitian ini menunjukkan bahwa nilai mean Budgetary Slack pada kondisi Asimetri Informasi rendah adalah sebesar 0,32681, sedangkan pada kondisi Asimetri Informasi tinggi adalah sebesar 0,75614 . Hasil tersebut sesuai dengan hasil penelitian dari Tri Siwi Nugrahani (2005) yang menyatakan bahwa manajer bawah dengan kondisi asimetri tinggi cenderung menciptakan Budgetary Slack yang lebih tinggi apabila dibandingkan dengan kondisi Asimetri Informasi rendah.

Hipotesis ketiga $\left(\mathrm{H}_{3}\right)$ dalam penelitian ini berlandaskan pada teori Jensen dan Meckling (1976) yang menyatakan bahwa hubungan agency terjadi ketika satu orang atau lebih principal mempekerjakan orang lain (agent) untuk melakukan jasa dan kemudian mendelegasikan wewenang terhadap agen tersebut (Rahmah dan Sembiring, 2014: 2), dimana dalam hubungan antara agent dan principal tersebut seringkali terjadi kondisi yang dinamakan Asimetri Informasi atau ketidakseimbangan informasi. Kondisi Asimetri Informasi ini memberikan peluang besar bagi manajer bawah untuk melakukan senjangan anggaran karena manajer atas tidak mengetahui kinerja aktual dari pusat pertanggungjawaban tersebut.

Tidak terbuktinya hipotesis ketiga $\left(\mathrm{H}_{3}\right)$ ini dimungkinkan penyebabnya adalah pada saat pelaksanaan eksperimen. Treatment Asimetri Informasi disajikan dalam bentuk uraian informasi, dimana peneliti tidak dapat menjamin bahwa partisipan benar-benar membaca dan memahami kasus tersebut. Kondisi kelas yang kurang kondusif memungkinkan mereka melewatkan untuk membaca treatment Asimetri Informasi yang telah disajikan.

\section{Keterbatasan Penelitian}

a. Penelitian ini menggunakan mahasiswa sebagai penyulih manajer penyusun anggaran. Tingkat pemahaman dan pengalaman yang berbeda antara mahasiswa dengan praktisi bisnis sesungguhnya dalam berbagai hal tentang penyusunan anggaran menyebabkan hasil 
penelitian ini tidak dapat digeneralisasikan untuk setiap kondisi.

b. Penggunaan mahasiswa sebagai penyulih manajer dapat menimbulkan bias pada hasil penelitian karena mahasiswa seringkali tidak membaca dan kurang memberikan perhatian dalam membaca informasi pada instrumen kasus secara keseluruhan.

c. Penelitian ini menggunakan instrumen berupa kasus dalam bentuk ilustrasi/abstraksi atau penyederhanaan dari situasi di dunia nyata dalam sebuah instrumen eksperimen yang belum bisa secara sepenuhnya mencerminkan kasus sebenarnya di lapangan.

d. Instrumen penelitian dalam bentuk kasus ilustrasi kurang dapat mengukur variabel yang diteliti, karena hanya ada satu perlakuan atau indikator untuk mengukur satu variabel.

e. Treatment yang diberikan melalui instrumen penelitian mungkin menimbulkan perbedaan persepsi dan pemahaman diantara partisipan dalam menginterpretasikan maksud treatment tersebut, sehingga memengaruhi respon partisipan.

f. Prosedur eksperimen dalam penelitian ini terlalu rumit dan panjang serta sulit dipahami, dimana setiap kali melakukan eksperimen ini membutuhkan waktu kurang lebih selama 20-30 menit, sehingga dimungkinkan menimbulkan kejenuhan bagi para partisipan.

g. Belum ada format penilaian yang baku untuk menilai validitas instrumen.

\section{SIMPULAN DAN SARAN}

\section{Simpulan}

a. Self Efficacy tidak berpengaruh terhadap Budgetary Slack. Hasil uji hipotesis pertama tersebut dapat diketahui dengan melihat nilai $\mathrm{F}$ hitung sebesar 0,008 lebih rendah dari $\mathrm{F}$ tabel yaitu sebesar 3,90 ( $\left.\mathrm{F}_{\text {hitung }}<\mathrm{F}_{\text {tabel }}\right)$ dan p-value Self Efficacy signifikansi sebesar $0,928>0,05$ yang menunjukkan tidak terdapat perbedaan nilai Budgetary Slack yang signifikan antara partisipan dengan kondisi Self Efficacy tinggi maupun Self Efficacy rendah. Nilai mean Budgetary Slack pada kondisi Self Efficacy rendah sebesar 0,41445 sedangkan pada kondisi Self Efficacy tinggi yaitu 0,65361 .

b. Pemberian Reward dan Punishment berpengaruh terhadap Budgetary Slack. Hal tersebut ditunjukkan oleh F hitung sebesar 8,362 lebih besar dari $\mathrm{F}$ 
tabel yaitu 3,90 ( $\left.\mathrm{F}_{\text {hitung }}>\mathrm{F}_{\text {tabel }}\right)$ dan $p$ value sebesar $0,004<0,05$ yang menunjukkan terdapat perbedaan nilai Budgetary Slack yang signifikan antara partisipan yang mendapatkan treatment Reward dan Punishment. Reward berpengaruh terhadap peningkatan Budgetary Slack yang lebih tinggi. Hal tersebut ditunjukkan dengan nilai rata-rata (mean) Budgetary Slack pada pemberian Reward sebesar 0,084706. Sementara Punishment berpengaruh terhadap penurunan Budgetary Slack yang lebih rendah. Hal tersebut ditunjukkan oleh nilai rata-rata (mean) Budgetary Slack pada pemberian Punishment sebesar 0,023031 .

c. Asimetri Informasi tidak berpengaruh terhadap Budgetary Slack. Hasil uji hipotesis pertama tersebut dapat diketahui dengan melihat nilai $\mathrm{F}$ hitung sebesar 0,186 lebih rendah dari $\mathrm{F}$ tabel yaitu sebesar 3,90 ( $\left.\mathrm{F}_{\text {hitung }}<\mathrm{F}_{\text {tabel }}\right)$ dan p-value Asimetri Informasi signifikansi sebesar 0,667 > 0,05 yang menunjukkan tidak terdapat perbedaan nilai Budgetary Slack yang signifikan antara partisipan dengan kondisi Asimetri Informasi tinggi maupun Asimetri Informasi rendah. Nilai mean Budgetary Slack pada kondisi Asimetri Informasi rendah sebesar 0,32681 sedangkan pada kondisi Asimetri Informasi tinggi yaitu 0,75614

\section{Saran}

\section{a. Bagi Perusahaan}

1) Perusahaan sebaiknya dapat memperkecil tingkat Asimetri Informasi antara manajer atas dengan manajer bawah, dapat dilakukan dengan cara semua informasi dari tiap pusat pertanggungjawaban diberikan secara terbuka dan menyeluruh bagi setiap tingkatan manajer dalam perusahaan.

2) Perusahaan sebaiknya perlu untuk mengetahui karakteristik kepribadian individu, salah satunya adalah Self Efficacy yang dimiliki karyawan. Hal ini karena dapat dimungkinkan karyawan yang memiliki Self Efficacy tinggi justru terlalu menganggap mudah suatu urusan sehingga mereka cenderung untuk berbuat sesuatu yang menyimpang. Sebaliknya karyawan dengan Self Efficacy rendah yang kurang merasa percaya akan kemampuan dirinya justru akan lebih tekun dan berusaha dengan baik untuk mencapai target 
anggaran tanpa harus melakukan slack.

3) Perusahaan sebaiknya dapat menerapkan sistem kompensasi Reward dan Punishment dengan kombinasi yang tepat agar karyawan tidak semata-mata hanya berorientasi pada Reward yang akan mereka terima atau konsekuensi Punishment yang akan mereka dapatkan.

b. Bagi Peneliti Selanjutnya

1) Penelitian selanjutnya sebaiknya dilakukan dengan menggunakan sampel manajer bawah atau karyawan penyusun anggaran sungguhan yang benar-benar terlibat secara langsung dalam proses penyusunan anggaran secara partisipatif.

2) Penelitian selanjutnya sebaiknya menyusun instrumen yang lebih baik, dimana setiap variabel penelitian tidak hanya diukur dengan satu treatment.

\section{DAFTAR PUSTAKA}

Abdullah, I.A. (2013). The Influence of Horizontal Equity, Self efficacy, and Ethical Position on the Creation of Budgetary Slack. Disertasi. Virginia Commonwealth University.

Anthony, Robert N., \& Vijay Govindarajan. (2011).
3) Penelitian selanjutnya sebaiknya menyajikan desain kasus eksperimen dengan lebih menarik, tidak hanya berupa angket yang berisi kasus perlakuan.

4) Penelitian selanjutnya sebaiknya memberikan treatment yang dapat dirasakan secara langsung oleh partisipan, sehingga mereka akan lebih menjiwai dalam mengikuti eksperimen. Seperti halnya dalam penelitian ini yang menggunakan Reward dan Punishment dalam bentuk nyata yang benar-benar diterima atau ditanggung oleh partisipan.

5) Peneliti selanjutnya, apabila menggunakan face validity untuk uji validitas instrumen sebaiknya menyusun format penilaian yang baku untuk penilaian validitas agar penilai memiliki pedoman dalam melakukan penilaian validitasnya.

Management Control System. (Alih bahasa: Drs. R. Suyoto Bakir. Jakarta: Salemba Empat.

Arthaswadaya, A. (2015). "Pengaruh Asimetri Informasi terhadap Budgetary Slack dengan Self Esteem sebagai Variabel Pemoderasi: Studi Eksperimen dalam Konteks Penganggaran 
Partisipatif. Skripsi. Universitas

Negeri Yogyakarta.

Falikhatun (2007). "Interaksi Informasi Asimetri, Budaya Organisasi, dan Group Cohesiveness dalam Hubungan Antara Partisipasi Penganggaran dan Budgetary Slack (Studi Kasus pada Rumah Sakit Umum Daerah se-Jawa Tengah)". Simposium Nasional Akuntansi (SNA) X. Makasar (2627 Juli 2007).

Ghozali, I. (2011). Aplikasi Analisis Multivariate dengan Program IBM SPSS 19. Edisi 5. Semarang: Badan Penerbit Universitas Semarang.

Ivancevich, Konpaske dan Matteson. (2007). Perilaku Manajemen dan Organisasi. (Alih Bahasa: Gina Gania). Jakarta: Erlangga.

Kreitner, Robert dan Angelo Kinicki. (2003). Perilaku Organisasi. Jakarta: Salemba Empat.

Ni Made Mila Rosa Desmayani dan I Made Sadha Suardikha. (2016). "Pengaruh Penganggaran Partisipatif, Locus of Control, dan Pemberian Reward terhadap Budgetary Slack". E-Jurnal Akuntansi Universitas Udayana. Vol. 16. 2.

Ni Putu Dewik Erina dan Wayan Suartana. (2016). "Pengaruh Partisipasi Penganggaran, Penekanan Anggaran, Kapasitas Individu, dan Kejelasan Sasaran Anggaran pada Senjangan Anggaran". E-Jurnal Akuntansi Universitas Udayana. Vol.15.2.
Nugrahani, T.S. (2005). "Pengaruh Kompensasi dan Asimetri Informasi pada Kesenjangan Anggaran". Jurnal Universitas PGRI Yogyakarta.

Rahayu, S \& Rachman, Andry Arifian. (2013). Penyusunan Anggaran Perusahaan. Yogyakarta: Graha Ilmu.

Rahmah, N.I \& Ferikawita M. Sembiring. (2014). "Suatu Tinjauan Teori Keagenan: Asimetri Informasi dalam Praktik Manajemen Laba". Artikel Ilmiah Univeristas Jenderal Achmad Yani. Hlm 1-6.

Silfiana. (2015). "Pengaruh Framming Effect, Kompensasi, dan Self efficacy terhadap Pengambilan Keputusan Investasi pada Mahasiswa Jurusan Pendidikan Akuntansi 2012 Universitas Negeri Yogyakarta". Skripsi. Universitas Negeri Yogyakarta.

Sugiharto, T. (2009). Analisis Varian. Modul. Universitas Gunadarma.

Wibisono, P.W. (2015). "Pengaruh Reward and Punishment dan Job Rotation terhadap Fraud. Skripsi. Universitas Negeri Yogyakarta. 